\title{
Optimalisasi Potensi Ekowisata Hutan Mangrove di Desa Pare Mas Kecamatan Jerowaru
}

\author{
Arum Dwi Setianingsih ${ }^{1}$, Amir Linda Tyas Hartatik ${ }^{1}$, Lalu Riki Gita Sukma ${ }^{2}$, Muh. Zubair ${ }^{3}$, Dian \\ Setiawati $^{2}$, Putri Devi Fitriati ${ }^{2}$, Ni Kadek Mardani Puspayanti \\ ${ }^{1}$ Pendidikan Bahasa Inggris, Fakultas Kegur, Universitas Mataram, Mataram, Indonesia \\ ${ }^{2}$ Pendidikan Matematika, FKIP, Universitas Mataram, Mataram, Indonesia \\ ${ }^{3}$ Pendidikan Pancasila dan Kewarganegaraan, FKIP, Universitas Mataram, Mataram, Indonesia \\ ${ }^{4}$ Pendidikan Biologi, FKIP, Universitas Mataram, Mataram, Indonesia
}

https://doi.org/10.29303/jpmpi.v3i2.1316

Sitasi: Septianingsih, A. D., Hartatik, A. L. T., Sukma, L. R. G., Zubair, M., Setiawati, D., Fitriani, P. D., Fitriani, P. D \& Puspayanti, N. K. M. (2022). Optimalisasi Potensi Ekowisata Hutan Mangrove di Desa Pare Mas, Kecamatan Jerowaru. Jurnal Pengabdian Magister Pendidikan IPA, 5(1)

\author{
Article history \\ Received: 11 Januari 2022 \\ Revised: 01 Februari 2022 \\ Accepted: 07 Februari 2022 \\ *Corresponding Author: Arum \\ Dwi Setianingsih, Fakultas \\ Keguruan dan Ilmu Pendidikan, \\ Universitas Mataram, Mataram, \\ Indonesia; \\ Email: \\ arumdwisetianingsih@gmail.com
}

\section{Pendahuluan}

$\mathrm{M}$ angrove merupakan suatu tempat yang bergerak akibat adanya pembentukan tanah lumpur dan dataran secara terus-menerus sehingga secara perlahan berubah menjadi semi daratan (Arief, 2003). Ekosistem mangrove adalah suatu sistem di alam tempat berlangsungnya kehidupan yang mencerminkan hubungan timbal balik antara makhluk hidup dan lingkungannya, dan diantara mahluk hidup itu sendiri terdapat pada wilayah pesisir, pengaruh pasang surut air laut dan di dominasi oleh spesies pohon atau yang khas dan mampu tumbuh dalam perairan asih/payau (Santoso, 2000). Hutan mangrove yang biasanya juga disebut dengan hutan bakau mempunyai karakteristik yang khas, mengingat hidupnya berada di daerah ekotone yaitu perairan dan daratan. Hutan mangrove merupakan suatu ekosistem yang mempunyai peranan sangat penting ditinjau dari sisi ekologis maupun aspek sosial ekonomi. Diantaranya ekosistem ini berfungsi sebagai perlindungan pantai secara alami untuk mengurangi resiko terhadap bahaya abrasi (Majid, et al., 2016).

Potensi hutan mangrove yang ada di Desa Pare Mas, Kecamatan Jerowaru hingga saat ini masih belum dioptimalkan dengan baik. Hal ini berdasarkan observasi yang telah dilakukan, yang mana permasalahannya adalah belum adanya sumber daya manusia yang terorganisir secara khusus ditempatkan untuk mengelola hutan mangrove dikarenakan sedikitnya penduduk yang ada di Desa Pare Mas serta jarak rumah warga yang terlalu jauh. Jika ditinjau dari aspek sosial 
masyarakat, pengelolaan hutan mangrove di Desa Pare Mas, Kecamatan Jerowaru sudah ada yang melibatkan masyarakat sekitar, akan tetapi tidak terlalu banyak sehingga tidak optimal untuk mengelola hutan mangrove sebagai ekowisata. Kemudian, jika ditinjau dari aspek ekonomi, masih minimnya pengetahuan masyarakat sekitar akan kegunaan mangrove sebagai sumber ekonomi masyarakat yang bisa dijadikan salah salah satu indikator pendorong peningkatan ekonomi.

\section{Metode}

Adapun program kerja yang telah dilakukan yaitu Festival Balap Sampan Mini, Pembuatan Spot Foto, Penunjang Kebersihan Area Wisata yang dibagi menjadi 3 kegiatan yaitu Pengecatan Bak Sampah, Pembuatan Plang Kebersihan, Pembersihan Area Wisata dan Pantai, serta Promosi Wisata.

\section{1) Waktu dan Tempat}

a. Festival Balap Sampan Mini

Festival Balap Sampan Mini dilaksanakan di Area Wisata Desa Pare Mas, Kecamatan Jerowaru, Kabupaten Lombok Timur, Nusa Tenggara Barat pada 23 - 26 Desember 2021.

b. Pembuatan Spot Foto

Pembuatan Spot Foto dilaksanakan di lokasi mahasiswa KKN Desa Pare Mas, Kecamatan Jerowaru, Kabupaten Lombok Timur, Nusa Tenggara Barat pada 6 - 19 Desember 2021.

c. Penunjang Kebersihan Area Wisata

1. Pengecatan Bak Sampah

Pada 3, 4, 10, dan 11 Desember 2021 telah dilaksanakan Pengecatan Bak Sampah di sekitar Area Wisata Desa Pare Mas, Kecamatan Jerowaru, Kabupaten Lombok Timur, Nusa Tenggara Barat.

2. Pembuatan Plang Kebersihan

Pada 11, 12, 18 dan 19 Desember 2021 telah dilaksanakan Pembuatan Plang Kebersihan di lokasi mahasiswa KKN Desa Pare Mas, Kecamatan Jerowaru, Kabupaten Lombok Timur, Nusa Tenggara Barat.

3. Pembersihan Area Wisata dan Pantai

Pada 12 dan 19 Desember 2021 telah dilaksanakan Pembersihan Area Wisata di sekitar Area Wisata Desa Pare Mas, Kecamatan Jerowaru, Kabupaten Lombok Timur, Nusa Tenggara Barat.

\section{d. Promosi Wisata}

Promosi Wisata dilaksanakan di Area Wisata dan Lesehan Terapung Desa Pare Mas, Kecamatan Jerowaru, Kabupaten Lombok Timur, Nusa Tenggara Barat pada $29-31$ Desember 2021.

\section{2) Alat dan Bahan}

a. Festival Balap Sampan Mini

Alat yang dibutuhkan dalam Festival Balap Sampan Mini adalah sampan beserta mesin, sound system, mikrofon serta penyangga garis start dan finish. Sedangkan bahan yang dibutuhkan dalam kegiatan ini berupa kayu dan tali rafia.

\section{b. Pembuatan Spot Foto}

Alat yang dibutuhkan dalam Pembuatan Spot Foto adalah mesin las, pemotong besi dan gunting. Sedangkan bahan yang dibutuhkan dalam kegiatan ini adalah besi, skrup, plat, semen, dan pilok berwarna hitam, emas, merah bata, hijau tua, dan hijau daun.

c. Penunjang Kebersihan Area Wisata

1. Pengecatan Bak Sampah

Pengecatan Bak Sampah membutuhkan alat yaitu kuas besar, kuas kecil dan pensil. Sedangkan bahan yang dibutuhkan yaitu cat berwarna hijau dan hitam.

2. Pembuatan Plang Kebersihan

Pembuatan Plang Kebersihan membutuhkan alat yaitu gergaji dan kuas. Sedangkan bahan yang dibutuhkan yaitu kayu, cat berwarna hitam, dan spidol putih. 3. Pembersihan Area Wisata dan Pantai

Pembersihan Area Wisata dan Pantai membutuhkan alat yaitu sapu lidi, sekop dan alat pemotong rumput. Sedangkan bahan yang diperlukan yaitu kantong sampah atau trash bag.

d. Promosi Wisata

Alat yang dibutuhkan dalam Promosi Wisata adalah kamera handphone. Sedangkan bahan yang dibutuhkan dalam kegiatan ini adalah materi untuk mempromosikan area wisata yang ada di Pare Mas.

\section{3) Bentuk Kegiatan}

a. Festival Balap Sampan Mini

Bentuk kegiatan dari Festival Balap Sampan Mini ialah kompetisi balap sampan mini yang dilakukan oleh joki atau peserta dari berbagai dusun yang ada di Desa Pare Mas. Kegiatan tersebut terdiri dari beberapa rangkaian yaitu koordinasi terkait dengan lomba Balap Sampan Mini dengan pemuda dan masyarakat Pare Mas, 
pembuatan surat undangan, pembuatan poster, penyebaran undangan dan poster kepada Kepala Dusun ataupun ketua RT/RW, persiapan pembelian hadiah, technical meeting, festival balap sampan mini, hingga pemberian hadiah kepada pemenang. Tujuan dari kegiatan ini yaitu untuk memperkenalkan miniatur sampan mini yang dihasilkan oleh masyarakat Desa Pare Mas sehingga dapat dikenal oleh masyarakat secara luas dan dapat menjadi pendapatan bagi masyarakat jika dapat dipromosikan hingga tingkat nasional maupun internasional.

b. Pembuatan Spot Foto

Bentuk kegiatan dari Pembuatan Spot Foto ialah merancang dan membuat plang. Adapun plang bertuliskan "Ekowisata Hutan Mangrove Desa Pare Mas". Kegiatan tersebut terdiri dari pembuatan desain plang, survei tempat pembuatan plang, pembelian alat dan bahan plang, proses pembuatan plang, hingga pemasangan plang "Ekowisata Hutan Mangrove Desa Pare Mas". Tujuan dari kegiatan ini yaitu untuk memperkenalkan bahwa Desa Pare Mas merupakan Desa Ekowisata sehingga hal ini dapat membuat para wisatawan penasaran dan tertarik untuk mengenal dan mengunjungi Desa Pare Mas.

c. Penunjang Kebersihan Area Wisata

1. Pengecatan Bak Sampah

Bentuk kegiatan dari Pengecatan Bak Sampah yaitu membuat bak sampah agar terlihat dengan melakukan pengecatan dan menggambarnya. Adapun gambar yang ada di bak sampah yaitu seseorang yang sedang membuang sampah pada tempatnya. Kegiatan pengecatan bak sampah terdiri dari pembelian kuas, cat berwarna hijau dan hitam serta pengecatan dan menggambar bak sampah. Tujuan dari kegiatan ini agar bak sampah lebih terlihat dan memperindah tampilan dari bak sampah.

2. Pembuatan Plang Kebersihan

Bentuk kegiatan dari Pembuatan Plang Kebersihan yaitu membuat plang yang bertuliskan himbauan-himbauan mengenai cara menjaga lingkungan. Adapun himbauan yang dituliskan yaitu Buang Sampah Disini dan Dendek Teteh Dedoro Lek Te. Kegiatan pembuatan plang kebersihan terdiri dari pemotongan kayu, pembelian cat berwarna hitam dan spidol putih, penulisan himbauan menjaga lingkungan di plang serta pemasangan plang kebersihan di area wisata. Tujuan dari pembuatan plang kebersihan yaitu untuk menyadarkan masyarakat pentingnya menjaga kebersihan dan agar para wisatawan yang datang ke Desa Pare Mas selalu menjaga kebersihan di area wisata.

3. Pembersihan Area Wisata dan Pantai

Bentuk kegiatan dari Pembersihan Area Wisata dan Pantai yaitu kegiatan bersihbersih di area wisata dan pantai yang ada di Desa Pare Mas. Kegiatan pembersihan area wisata dan pantai ini terdiri dari koordinasi dengan perangkat Desa mengenai jadwal pembersihan, peminjaman alat kebersihan serta pembersihan area wisata dan pantai. Tujuan pembersihan area wisata dan pantai yaitu untuk menanamkan kesadaran masyarakat agar tetap menjaga lingkungan di area wisata maupun pantai.

d. Promosi Wisata

Bentuk kegiatan dari Promosi Wisata ialah mempromosikan objek wisata yang ada di Desa Pare Mas melalui video. Adapun objek wisata yang akan diperkenalkan yaitu dermaga, hutan mangrove, beserta lesehan terapung yang ada di Desa Pare Mas. Kegiatan tersebut terdiri dari persiapan materi objek wisata yang akan dikenalkan, pengambilan video objek wisata yang ada di Desa Pare Mas, pengeditan video serta mengunggah video di media sosial seperti YouTube dan Instagram. Tujuan dari kegiatan ini yaitu untuk memperkenalkan objek wisata yang ada di Pare Mas secara lebih luas melalui media sosial.

\section{4) Metode}

Keseluruhan program menggunakan metode deskriptif kualitatif. Menurut Sugiyono (2016), metode deskriptif kualitatif adalah metode penelitian yang berdasarkan pada filsafat postpositivisme digunakan untuk meneliti pada kondisi objek yang alamiah (sebagai lawannya adalah eksperimen) dimana peneliti adalah sebagai instrumen kunci teknik pengumpulan data dilakukan secara triangulasi (gabungan), analisis data bersifat induktif/kualitatif, dan hasil penelitian kualitatif lebih menekankan makna daripada generalisasi. Sedangkan menurut I Made Winartha (2006:155), metode analisis deskriptif kualitatif adalah menganalisis, menggambarkan, dan meringkas berbagai kondisi, situasi dari berbagai data yang dikumpulkan berupa hasil wawancara atau pengamatan mengenai masalah yang diteliti yang terjadi di lapangan. Jenis data yang digunakan adalah 
primer dan sekunder dengan teknik pengumpulan data melalui observasi lapangan, wawancara, dan studi pustaka. Semua data tersebut diolah dan dianalisis sedemikian rupa sehingga dapat ditarik kesimpulan pada akhirnya.

\section{Hasil dan Pembahasan}

\section{1) Festival Balap Sampan Mini}

Festival balap sampan mini merupakan kegiatan tahunan yang kerap dilaksanakan di Desa Pare Mas, Kecamatan Jerowaru, Kabupaten Lombok Timur. Kegiatan ini biasanya diadakan oleh pemuda Desa Pare Mas yang berkolaborasi dengan mahasiswa KKN. Pelaksanaan festival

balap sampan mini ini merupakan salah satu bentuk promosi wisata dikarenakan sampan mini yang digunakan dalam kegiatan ini merupakan hasil karya masyarakat Desa Pare Mas sehingga diharapkan dengan adanya kegiatan ini, dapat menarik wisatawan untuk untuk mengunjungi Desa Pare Mas. Selain itu, kegiatan ini dilakukan di area wisata sehingga dapat sekaligus memperkenalkan ekowisata hutan mangrove yang ada di desa.

Kegiatan balap sampan mini diadakan selama 4 hari yang mana dimulai dari tanggal $23-26$ Desember 2021. Rangkaian kegiatan yang dilaksanakan meliputi koordinasi terkait dengan lomba balap sampan mini dengan pemuda dan masyarakat Pare Mas, pembuatan surat undangan, pembuatan poster, penyebaran undangan dan poster kepada Kepala Dusun ataupun ketua RT/RW, persiapan pelaksanaan festival balap sampan mini, technical meeting, serta pelaksanaan festival Balap Sampan Mini.

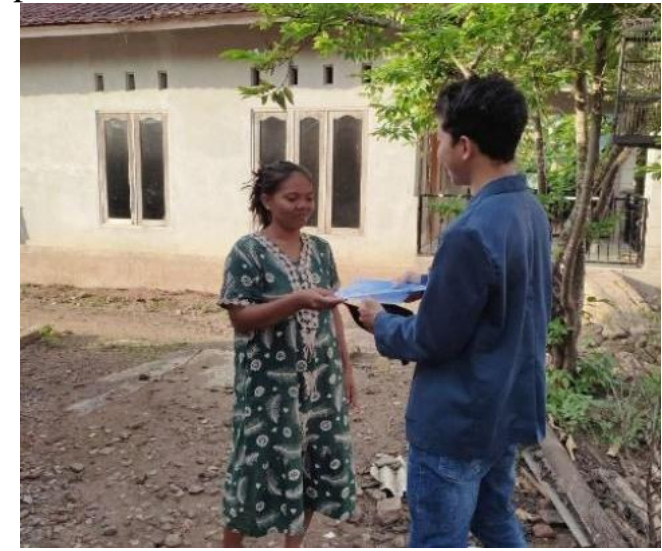

Gambar 1 Penyebaran Surat Undangan dan Poster Festival Balap Sampan Mini

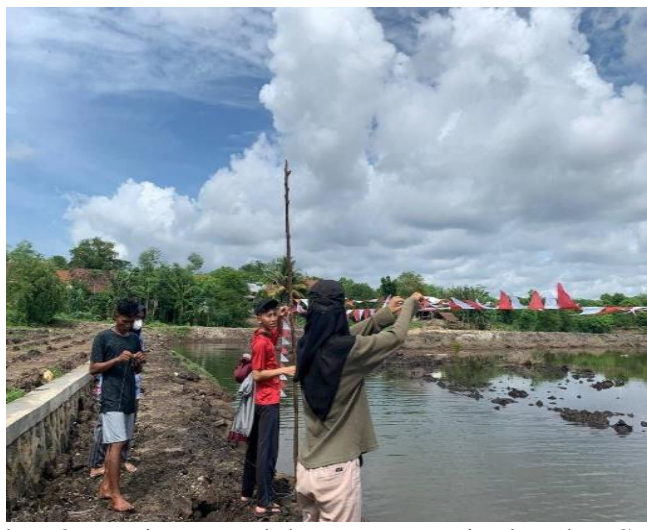

Gambar 2 Persiapan Pelaksanaan Festival Balap Sampan Mini

Persiapan pelaksanaan festival balap sampan mini dilakukan selama 3 hari. Kegiatan yang dilakukan meliputi pembuatan umbul-umbul dan bendera, pembelian hadiah, pemasangan umbulumbul dan bendera di lintasan festival balap sampan mini, serta pemasangan garis start dan garis finish. Technical meeting dilaksanakan pada hari pertama festival balap sampan mini yaitu pada 23 Desember 2021.

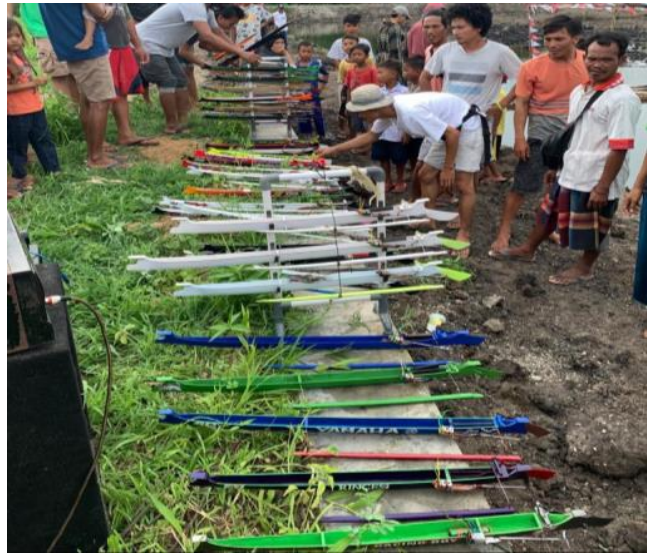

Gambar 3 Sampan Mini untuk Festival Balap

Total peserta yang mengikuti festival balap sampan mini sebanyak 41 peserta dengan menggunakan sistem penyisihan selama 3 hari, untuk selanjutnya diadakan babak final di hari terkahir. Adapun 4 besar dalam Festival Balap Sampan Mini ini diraih oleh Broiler dengan joki yaitu Aef sebagai juara 1, The Doctor 2 dengan joki yaitu Mus sebagai juara 2, Brangush dengan joki yaitu Doni sebagai juara 3 dan Double Solo dengan joki yaitu Riska sebagai juara 4 . 


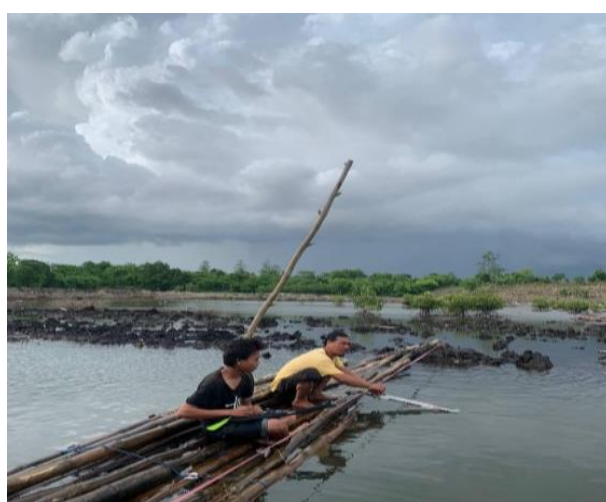

Gambar 4 Festival Balap Sampan Mini

Kegiatan Festival Balap Sampan yang dilakukan, berhasil menarik atensi masyarakat secara luas dan memberikan dampak yang positif. Hal ini dikarenakan masyarakat yang hadir, tidak hanya berasal dari Desa Pare Mas, namun terdapat pula masyarakat dari desa lainnya. Sehingga ekowisata yang ada di Desa Pare Mas dapat diketahui oleh masyarakat secara lebih luas

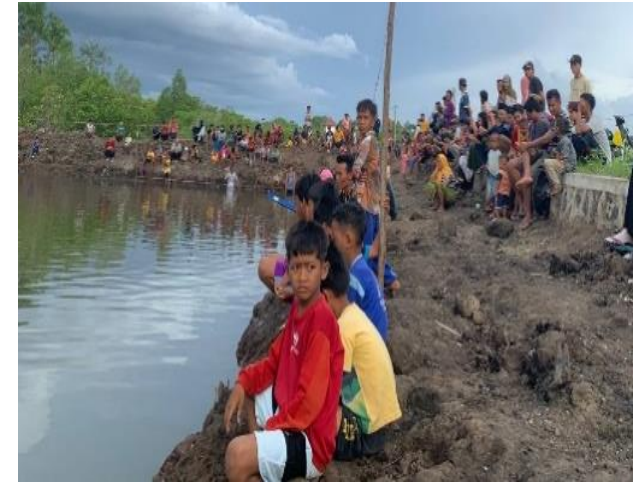

Gambar 5 Pelaksanaan Final Festival Balap Sampan Mini

\section{2) Pembuatan Spot Foto}

Pembuatan Spot Foto merupakan hal yang tidak dapat dipisahkan dengan tempat wisata. Keberadaan spot foto yang menarik akan memengaruhi jumlah wisatawan yang datang berkunjung. Oleh karena itu, maka dibutuhkan spot foto yang sesuai dengan kebutuhan dan kondisi tempat wisata. Adanya spot foto di suatu tempat wisata dapat dimaksudkan sebagai upaya untuk menjadikan tempat wisata menjadi lebih dikenal oleh masyarakat luas. Melihat besarnya pengaruh spot foto terhadap perkembangan suatu objek wisata, maka mahasiswa KKN Terpadu Universitas Mataram memprogramkan pembuatan spot foto sebagai program kerja dalam upaya optimalisasi potensi ekowisata hutan mangrove di Desa Pare Mas.

Proses pembuatan spot foto ekowisata hutan mangrove di Desa Pare Mas dilaksanakan selama 26 hari. Rangkaian kegiatan yang dilakukan yaitu, design spot foto, survei tempat pembuatan spot foto, pembelian alat dan bahan, proses pembuatan, dan pemasangan spot foto. Design spot foto dilaksanakan selama 6 hari. Design spot foto yang dibuat terdiri atas tulisan "Ekowisata Mangrove Desa Pare Mas" dengan logo lobster menggunakan mahkota daun mangrove. Logo lobster dipilih dikarenakan Desa Pare Mas merupakan Desa penghasil Lobster, sedangkan logo mahkota daun mangrove melambangkan hutan mangrove yang terdapat di Desa Pare Mas.

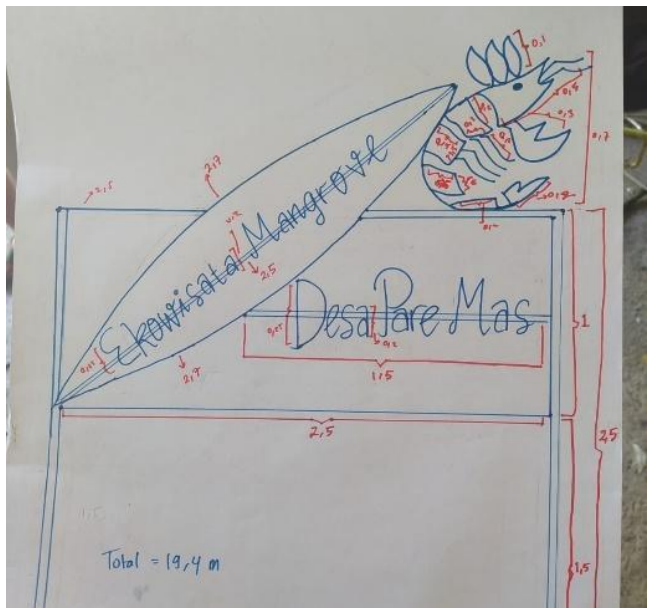

Gambar 6 Rancangan Pembuatan Spot Foto

Kegiatan selanjutnya yang dilaksanakan setelah design spot foto adalah survei tempat pembuatan spot foto. Survei ini dilaksanakan selama 4 hari. Kegiatan survei ini meliputi diskusi terkait estimasi biaya pembuatan, bahan-bahan yang dibutuhkan dalam pembuatan spot foto, dan penyerahan design spot foto kepada tukang las.

Pembelian alat dan bahan yang digunakan dalam pembuatan spot foto berlangsung selama 1 hari. Alat dan bahan yang dibeli yaitu besi sepanjang $19,4 \mathrm{~m}$, plat besi sebanyak 2 buah dengan panjang 2 $\times 1 \mathrm{~m}$, gunting untuk plat besi, skrup, dan pilok berwarna hitam, emas, merah bata, hijau tua, dan hijau daun. Pelaksanaan pembuatan spot foto berlangsung selama 14 hari. Kegiatan yang dilakukan dalam proses pembuatan spot foto adalah merangkai besi sebagai tempat menempelnya tulisan dan gambar logo Lobster, pembuatan tulisan dan gambar logo menggunakan plat besi, penyatuan tulisan dan gambar logo menggunakan sekrup, dan pewarnaan spot foto dengan pilok. 


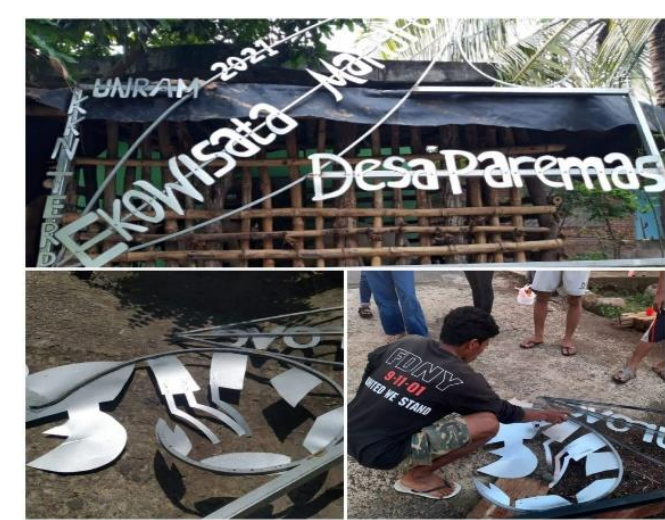

Gambar 7 Proses Pembuatan Spot Foto

Kegiatan terakhir yang dilaksanakan dalam pembuatan spot foto adalah pemasangan spot foto. Spot foto yang sudah jadi, akan dipasang di sebelah kanan plang Selamat Datang Ekowisata Mangrove Desa Pare Mas yang berjarak kurang lebih 1 meter. Beberapa kendala yang ditemukan dalam proses pembuatan spot foto ini adalah desain spot foto dan proses pewarnaan spot foto. Kendala dalam desain adalah sulitnya menemukan pola besi spot foto yang sesuai dan kesulitan menyesuaikan ukuran spot foto. Sementara kendala dalam proses pewarnaan adalah warna pada spot foto menumpuk dikarenakan rangka besi, tulisan, serta logo tidak diberikan pewarnaan secara terpisah.

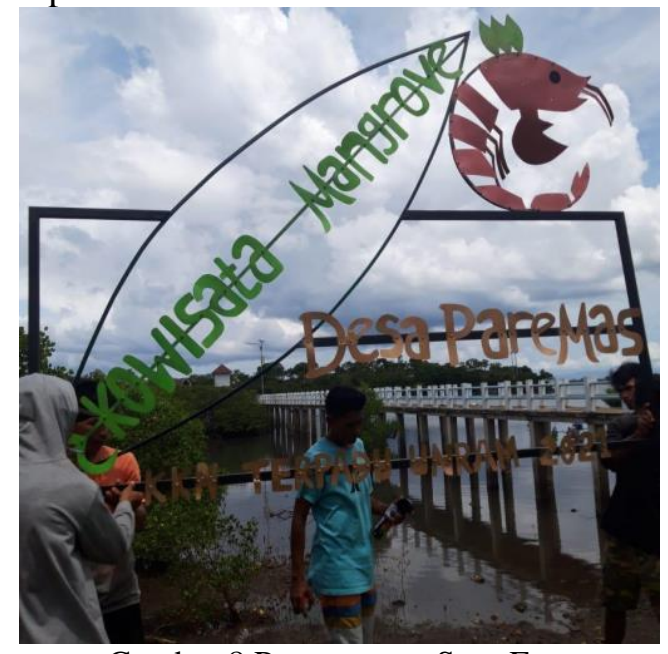

Gambar 8 Pemasangan Spot Foto

3) Penunjang Kebersihan Area Wisata

a) Pengecatan Bak Sampah

Sampah merupakan salah satu permasalahan di Indonesia yang sampai saat ini sangat susah diatasi. Sampah dapat bersumber dari produk industri, rumah tangga, maupun lingkungan sekitar. Berdasarkan survei yang telah dilakukan, mahasiswa KKN melihat banyaknya sampah yang berserakan di sekitar area masuk menuju tempat wisata sehingga mahasiswa KKN memprogramkan untuk melakukan pengecatan bak sampah yang sudah tersedia agar masyarakat dapat membuang sampah pada tempatnya dan para pengunjung dapat mengetahui tempat pembuangan sampah saat berkunjung ke area wisata di Desa Pare Mas.

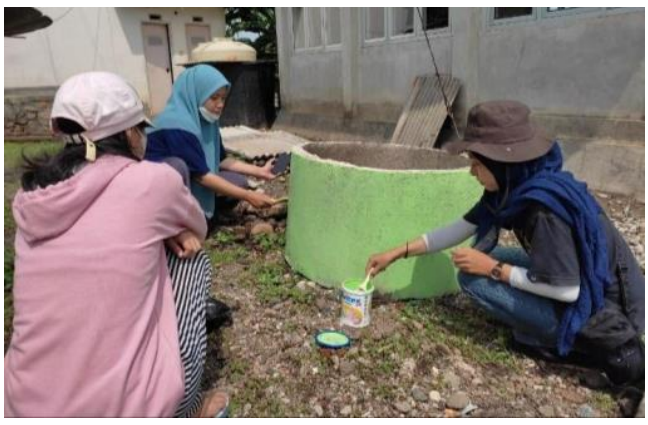

Gambar 9 Proses Pengecatan Bak Sampah

Pengecatan bak sampah dilaksanakan selama empat hari. Rangkaian kegiatan terdiri dari persiapan alat dan bahan serta proses pengecatan. Persiapan alat dan bahan dilaksanakan selama dua hari. Alat dan bahan yang dibutuhkan yaitu kuas besar dan kecil, cat warna hijau dan hitam, serta pensil. Selain itu, proses pengecatan dilaksanakan selama dua hari. Proses pengecatan pertama untuk mengecat warna dasar bak sampah. Sementara kegiatan dalam proses pengecatan kedua adalah menggambar sketsa pola gambar dan tulisan yang akan dibuat di atas bak sampah menggunakan pensil sebelum di cat dengan warna hitam.

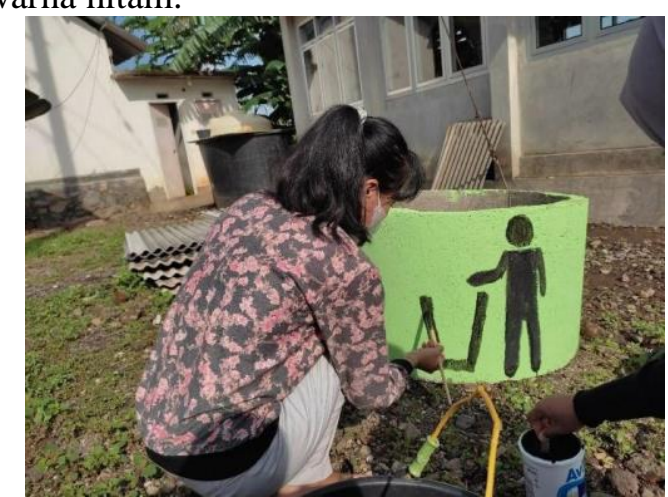

Gambar 10 Proses Penggambaran pada Bak Sampah

Beberapa kendala yang ditemukan dalam proses pengecatan bak sampah ini yaitu cuaca yang tidak menentu karena musim hujan yang menyebabkan kegiatan pengecatan sedikit terhambat. Kendala lain yang ditemukan adalah warna cat pada pola gambar dan tulisan yang tidak menyatu dengan warna cat dasar sehingga perlu dilakukan pengecatan berulang kali.

b) Pembuatan Plang Kebersihan 
Lingkungan merupakan segala sesuatu yang ada di sekitar dan dapat mempengaruhi kehidupan manusia. Sampah merupakan material sisa yang tidak diinginkan setelah berakhirnya suatu proses. Perilaku masyarakat sangat mempengaruhi keberadaan sampah. Pembuangan sampah sembarangan yang dilakukan oleh masyarakat mempengaruhi kondisi lingkungan dan kondisi perairan yang ada di Desa Pare Mas. Oleh karena itu, Mahasiswa KKN Terpadu Universitas Mataram memprogramkan kegiatan yaitu pembuatan plang kebersihan di sekitar area wisata Desa Pare Mas. Hal ini dilakukan karena masih kurangnya kesadaran masyarakat untuk membuang sampah pada tempatnya dan memilih membuang sampah di pinggiran rumah ataupun langsung membuangnya di pantai.

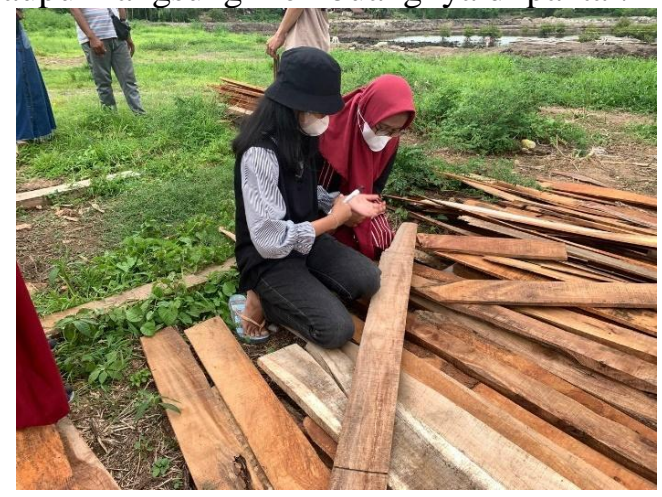

Gambar 11 Proses Pemilihan Bahan Plang Kebersihan

Program kerja ini dilaksanakan pada minggu ke-3 dan ke-4 dari jadwal kerja mahasiswa KKN. Plang yang dibuat terbuat dari kayu bekas proyek yang tidak terpakai namun masih dalam kondisi yang bagus yang nantinya akan ditulis himbauan untuk jangan membuang sampah sembarangan dan selalu menjaga kebersihan dalam Bahasa Indonesia dan juga Bahasa Sasak.

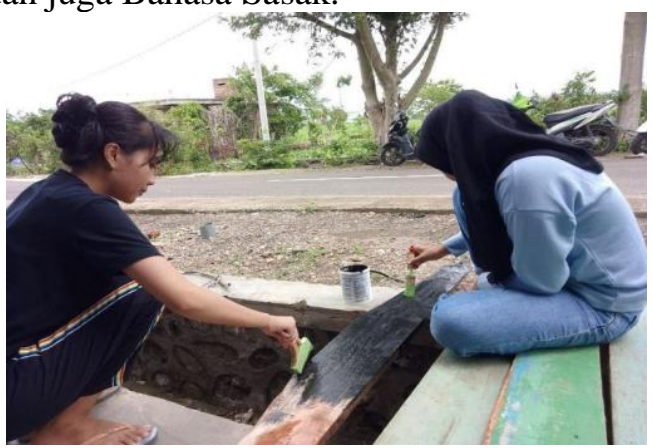

Gambar 12 Proses Pembuatan Plang Kebersihan

Adapun kendala dalam pembuatan plang kebersihan ini adalah dalam pemilihan kayu, kayu yang dipakai harus dalam kondisi yang masih layak untuk dijadikan plang dan yang tidak gampang lapuk. Pembuatan plang kebersihan ini diharapkan mampu menyadarkan masyarakat akan pentingnya menjaga kebersihan dan hal ini juga berlaku untuk pengunjung agar tetap menjaga kebersihan pada saat berkunjung ke area wisata. Berikut gambar plang kebersihan yang sudah selesai dan siap untuk diletakkan di area wisata Desa Pare Mas.

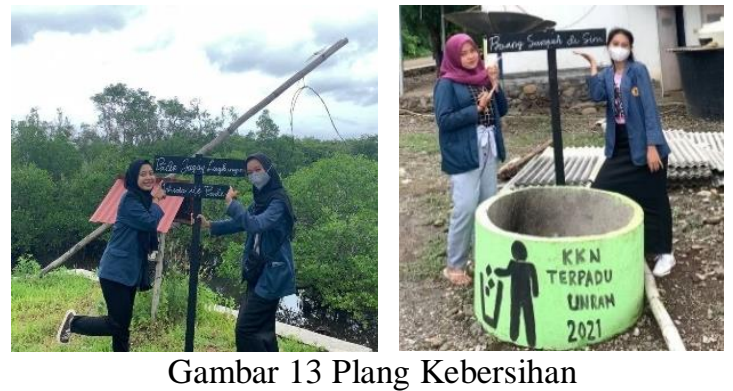

c) Pembersihan Area Wisata dan Pantai

Kegiatan aksi bersih pantai merupakan bagian dari upaya masyarakat untuk peduli terhadap kebersihan lingkungan pesisir. Seiring berkembangnya sektor pariwisata, terdapat berbagai permasalahan diantaranya terjadinya degradasi lingkungan, pencemaran lingkungan dan sampah yang dibuang secara sembarangan.

Mahasiswa KKN memprogramkan kegiatan bersih-bersih di area wisata dan juga di pinggiran pantai Desa Pare Mas. Program ini dilaksanakan dikarenakan banyaknya sampah plastik yang masih terlihat berserakan di sembarang tempat di dekat area wisata dan juga di area pantai. Kegiatan pembersihan di area wisata dan pantai ini dilakukan sekali seminggu di pagi hari yang dibantu oleh masyarakat dan anak-anak. Alat yang digunakan yaitu sapu lidi, sekop dan pemotong rumput. Lalu bahan yang digunakan yakni trash bag guna mengumpulkan sampah-sampah plastik untuk dibuang di bak sampah yang tersedia di area wisata. Setelah kegiatan bersih-bersih, area wisata dan area pantai terlihat rapi dan bersih tanpa ada sampah plastik, serta diharapkan view tersebut akan tetap terlihat seperti itu di harihari berikutnya. 


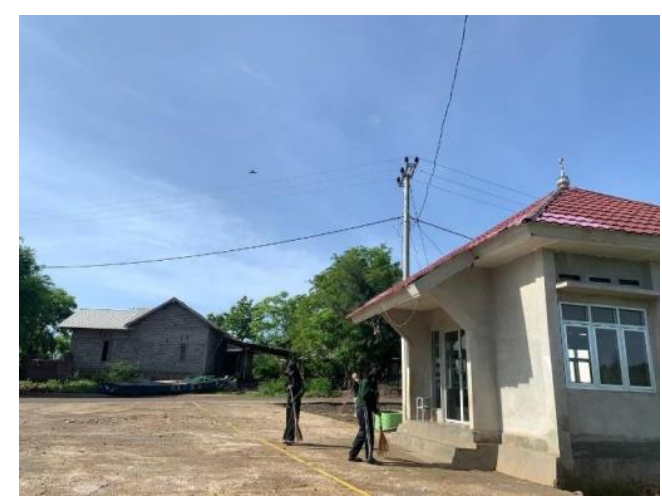

Gambar 14. Pembersihan Area Wisata

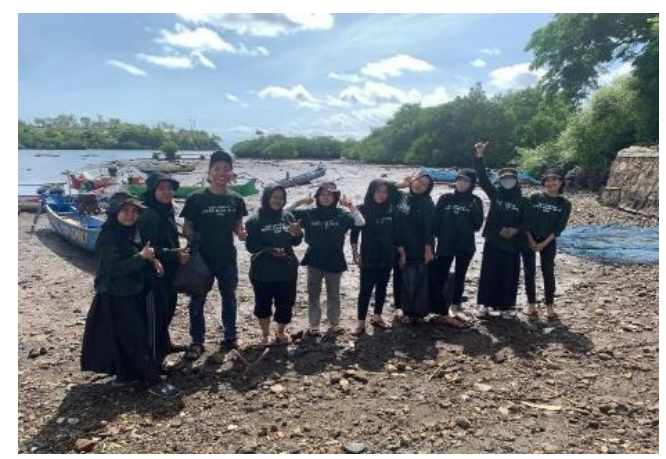

Gambar 15 Pembersihan Area Pantai

\section{4) Promosi Wisata}

Desa Pare Mas merupakan salah satu Desa di Kecamatan Jerowaru, Lombok timur yang sedang gencar mempromosikan sektor pariwisata yang dimiliki. Desa Pare Mas dapat terbilang cukup baik dalam pengembangan di bidang pariwisata. Sektor pariwisata yang dimiliki Desa Pare Mas diantaranya adalah wisata hutan mangrove, dermaga dan juga lesehan terapung. Ketiga tempat ini masih terdengar sangat asing pada masyarakat luar Desa Pare Mas. Oleh karena itu, perlunya dilakukan promosi wisata untuk memperkenalkan ketiga tempat wisata tersebut pada khalayak luar dengan cara promosi.

Melihat dari potensi wisata yang ada namun belum dikenal masyarakat secara luas, maka mahasiswa KKN Terpadu Universitas Mataram membuat program promosi wisata di Desa Pare Mas. Promosi wisata yang akan dilakukan yaitu memanfaatkan platform media sosial yang banyak penggunanya. Platform yang dimaksud ialah Instagram dan YouTube. Dalam platform media sosial tersebut, mahasiswa KKN akan mengulas tentang potensi wisata yang ada di desa Pare Mas termasuk ketiga tempat wisata di atas yang mana diambil dalam bentuk gambar ataupun dalam bentuk video. Pengambilan foto dan video menggunakan kamera ponsel dengan pencahayaan dan kestabilan yang sudah diatur sebelumnya. Gambar yang sudah diambil nantinya akan di edit untuk mendapatkan hasil foto yang lebih menarik. Setelah pengeditan, akan dilakukan pengunggahan di Instagram @kkn_paremas dan untuk video juga prosesnya sama yakni dilakukan pengeditan terlebih dulu sebelum diunggah di media sosial YouTube. Pengunggahan ke platform media sosial seperti Instagram dan YouTube ini diharapkan dapat dilihat ataupun ditonton oleh banyak orang kapanpun dan dimanapun. Maka dari itu, dapat dipastikan lebih banyak orang akan mengenal Desa Pare Mas memiliki sektor pariwisata yang tak kalah menarik dari sektor wisata di tempat lain di pulau Lombok ini. Berikut beberapa dokumentasi tempat wisata yang dimiliki Desa Pare Mas.

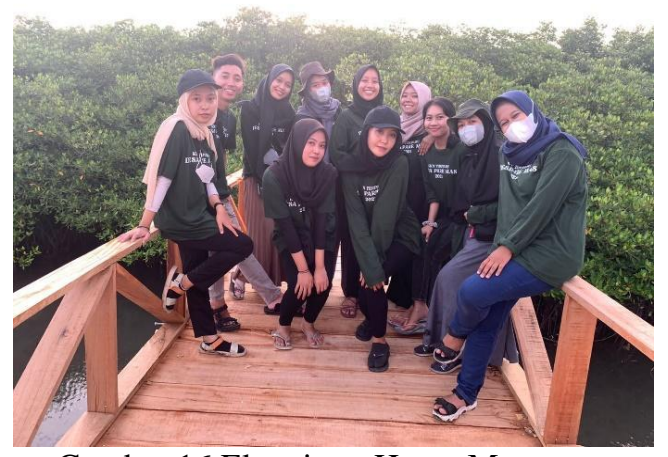

Gambar 16 Ekowisata Hutan Mangrove

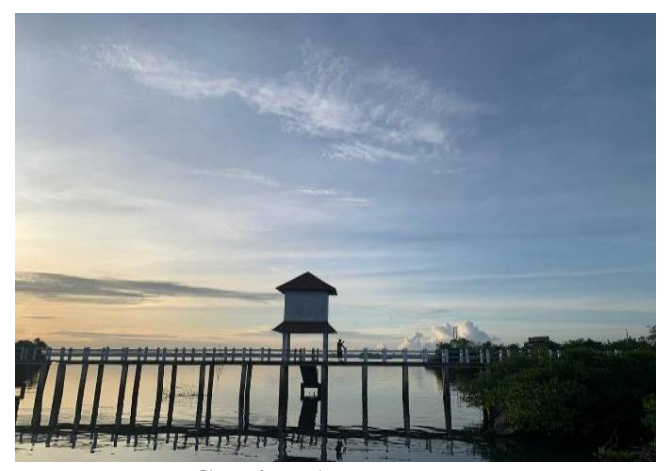

Gambar 17 Dermaga

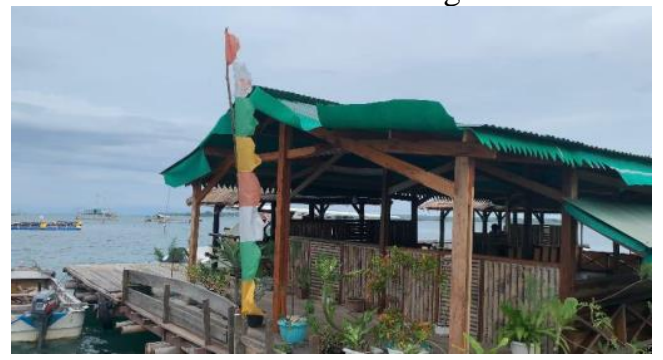

Gambar 18 Lesehan Terapung 


\section{Kesimpulan}

Berdasarkan penjabaran di atas, dapat disimpulkan bahwa ekosistem mangrove adalah suatu sistem di alam dimana terjadi hubungan timbal balik antara makhluk hidup dan lingkungannya yang terdapat di daerah pesisir. Potensi hutan mangrove yang ada di Pare Mas belum dapat dioptimalkan dengan baik dikarenakan sumber daya manusia yang masih minim akan pengetahuan dan fungsi dari mangrove itu sendiri. Oleh karena itu, KKN Desa Terpadu Universitas Mataram melaksanakan program kerja yaitu Pembuatan Spot Foto, Festival Balap Sampan Mini, Penunjang Kebersihan Area Wisata yang meliputi Pengecatan Bak Sampah, Pembuatan Plang Kebersihan, Pembersihan Area Wisata dan Pantai, serta Promosi Wisata sebagai upaya Optimalisasi Potensi Ekowisata Hutan Mangrove di Desa Pare Mas.

\section{Ucapan Terima Kasih}

Terima kasih kami ucapkan kepada Dosen Pembimbing Lapangan yang telah memberikan arahan, bimbingan, serta motivasi dalam pelaksanaan KKN Terpadu, FKIP, Universitas Mataram di Desa Pare Mas, Kecamatan Jerowaru, Kabupaten Lombok Timur. Ucapan terima kasih juga kami sampaikan kepada seluruh masyarakat yang telah membantu kami dalam menyelesaikan kegiatan ini dengan baik dari awal hingga akhir serta kami mengucapkan terima kasih kepada temanteman KKN Desa Pare Mas yang sudah bekerja sama dengan baik sehingga kegiatan ini dapat terlaksana dengan baik dan lancar tanpa hambatan apapun.

\section{Daftar Pustaka}

Rahim Sukiman., Dewi Wahyuni K. Baderan. 2017. Hutan Mangrove dan Pemanfaatnya. Deepublish. Yogyakarta.

Sugiyono. (2016). Metode Penelitian Kuantitatif, Kualitatif dan $R \& D$. Bandung: Alfabeta.

I Made Wirartha. 2006. Pedoman Penulisan Usulan Penelitian, Skripsi dan Tesis. Yogyakarta: Andi. 